が，副看護師長に着任した時点での思いや，その時の役割 認識に関して調査した論文は見当たらない. 看護師長をサ ポートするとともに, 看護スタッフの育成も担うといった, 副看護師長の任は重要であり, かつ多大な重責がかかって いる.そうした任にあたる者らの, 新規着任時の思いや役 割認識の理解について把握することは，その後のキャリア 発達や支援の在り方を明らかにすることにつながり，人材 育成への示唆, および看護の質向上に寄与すると考える.

\section{II 目的}

本研究は, 臨床現場において看護師長と看護スタッフの 中間に位置する副看護師長が, 新規着任時にどのような思 いを抱いているのか，そして自身の役割をどのように認識 しているのかを明らかにすることを目的とした。

\section{III 方法}

\section{1.用語の定義}

副看護師長：師長の次の職位である看護師

役割：所属している組織の中で, その地位に対し て認識している, あるいは遂行している務 め

\section{2. 研究デザイン}

本研究は, 自記式質問紙調査を用いた質的記述的研究で ある。

\section{3. 対象と調査方法}

\section{1 ) 対象者}

対象者は，X県において 2009 年度に副看護師長に任命 された看護職とし, 新任副看護師長研修の受講者 40 名と した.

\section{2 ) 調査期間}

2009 年 5 月

\section{3 ) 調査内容・方法}

自記式質問紙調査とし，「副看護師長の任に就いての自 身の思い」「今時点で認識している副師長の役割」「現在の 課題」について自由に記載してもらった. 用紙は, 対象者ら が参加する副看護師長の研修時に配布し, 研究について説 明するとともに, 研究への承諾が得られた者だけ回収した.

\section{4. 分析方法}

自記式質問紙調査に記載された内容は, Berelson, B. によ る内容分析の手法 ${ }^{11-14}$ に基づき質的帰納的に分析を行っ た. 各対象者の記載内容全体を文脈単位とした. 記載内容 のうち問いに対する内容を表す単語, 句, 文章を記録単位 とし, 文章の場合は主語と述語からなる一区切りを記録単 位とした，次に，個々の記録単位の文脈を歪めないように
配慮しながら抽象化し, コードとして抽出した. 抽出した コードを意味内容の類似性に従って分類し，その分類を忠 実に反映したサブカテゴリー名をつけた.さらに, 各サブ カテゴリーを意味内容の類似性に従って統合しカテゴリー 名をつけた. 抽出過程においては, 一定期間をおいてカテ ゴリー名, サブカテゴリー名の再確認を研究者間で行った. 最後に, 各カテゴリーに包含された記録単位の出現頻度を 数量化し,カテゴリー毎に集計した.

なお，分析にあたっては，質問紙に記載された内容をラ ンダムに配置したのちに, 上記の流れに従って分類した. そして, カテゴリーが抽出されたのち, サブカテゴリー, そ れを構成するコードを概観しながら, 新規着任時の思い, 認識している役割への分類を行った.

\section{5. 信頼性と妥当性の確保}

カテゴリーの信頼性を確保するため, 看護学分野の研究 者に再分析を依頼し, カテゴリーへの分類の一致率をス コットの計算式 ${ }^{11,14}$ に基づき算出し検討した. その際, 信頼 性を確保しているかどうかの判断基準は，一致率 70\%以 上 ${ }^{11,14}$ とした. 再分析を依頼する研究者は, 内容分析あるい は質的データを用いた研究の経験があること, また看護管 理に関する研究に携わつた経験があること,の 2 つの条件 を備えた者とした。

研究を進めるにあたり, 看護管理の研究に取り組んでい る専門家に適宜指導・評価を受けた。

\section{6. 倫理的配慮}

対象者へは, (1)研究の趣旨, (2)調査内容, (3)個人のプライ バシーの保護 (匿名性, 守秘義務の遵守), (4)研究参加意思 の自由および中止による不利益の有無, (5)研究参加への利 益および不利益とその対策, について文書および口頭にて 説明を行い, 同意書にて研究参加の同意を得た. また, 分析 結果の使用にあたっては, 匿名性, プライバシーの保護に 十分留意すること, データは研究の目的以外に使用しない ことを併せて説明した.

本研究は, 研究者の所属する機関の倫理委員会にて承認 (受付番号：09-2) を得て行った.

\section{IV 結果}

\section{1. 対象者の属性}

研究への承諾が得られた対象者は, 37 名であった. 男性 が 4 人 (10.8\%), 女性が 33 人 ( $89.2 \%)$, 平均年齢 $43.6 \pm 3.0$ 歳で 38 歳から 49 歳, 経験年数は, 平均 $21.3 \pm 3.7$ 年で 14 年から 29 年であった.

\section{2. 自記式質問紙調査結果の概要}

質問紙調査に書かれた記述は 37 文脈単位で, 合計 340 記録単位に分割できた.このうち, 副看護師長 (以下, 副師 
長) の新規着任時の思い, そして認識している役割につい て記述された 266 記録単位を分析対象とした。

266 記録単位を意味内容の類似性に基づき分類した結果, 新規着任時の思いには 5 つのカテゴリーが (116 記録単 位), 認識している役割についても5つのカテゴリー (150 記録単位) が抽出された. 以下，本文中では，カテゴリーは

【】, サブカテゴリーは《》, コードは「」，補語は (）で示す.

\section{3. 新規着任時の思い}

副師長に着任しての思いとして,【担うことへの煩悶】 【自身に必要とされる力への思案】【自身の評価に対する心 配】【着任への抵抗】【昇格への意気込み】の 5 つのカテゴ リーが抽出された (表 1).

新規着任時の思いとして, 41 記録単位 $(35.3 \%)$ と最も多 かったのが【担うことへの煩悶】であった.このカテゴリー は，《担うことへの重荷》《任務遂行への不安》の 2 つサ ブカテゴリーから構成された.「副師長の任は自分にとっ て責任が重い」「体力・知力の限界に加えてさらなる試練で ある」と, 対象者らの多くが副師長という役職を《担うこと への重荷》を感じていた. また，《任務遂行への不安》も強 く,「副師長の役目が果たせるか自信がない」「副師長とし てやっていけるのか心配である」と混沌とした気持ちを抱 えていた。

対象者らは, 着任にあたり【自身に必要とされる力への 思案】 (25 記録単位; $21.6 \%)$ を行っていた.このカテゴ リーは,《自身の立ち位置の理解》《知識の獲得》《モチベー ションの維持と向上》《コミュニケーション能力の向上》の 4 つのサブカテゴリーから構成された。《自身の立ち位置の 理解》には,「看護者として自分らしいあり方がつかめる」

「周りに振り回されない自分を持つ」といった記載がみら れた. 同様に, 《知識の獲得》として,「日々学習が必要であ る」「病棟の業務を実践していく為の知識を身につける」と いつた向上心が示されていた，他には，「問題意識を持つよ うにする」といった《モチベーションの維持と向上》,「人の
話がきけるリーダーになりたい」といった《コミュニケー ション能力の向上》についての記載がみられた.

対象者らは, 周囲からの【自身の評価に対する心配】(23 記録単位；19.8\%) を抱えており, 副師長としての能力があ るのか, といった自身の能力の程度や, 周囲から認められ ているだろうかといったことを気にかけていた．このカテ ゴリーは, 《自分の力量への不安》と《スタッフの反応を懸 念》の 2 つのサブカテゴリーから構成された. 《自身の力量 への不安》は,「人の上に立つという副師長の任は, 調整能 力のない自分には不安がある」「自ら企画・発案・行動をお こすことができない」といった副師長として必要とされる 力が不足していることを記載していた. また, 自身が副師 長になってから「態度が変わったスタッフがいるため, 不 安を持っていると思う」「何で自分が選ばれたのか, と周り も思っている」といった《スタッフの反応を懸念》してい る者もいた。

【着任への抵抗】(22 記録単位；19.0\%) は，《選任された ことへの疑問》《今までの実績と未練》の 2 つのサブカテ ゴリーから構成された. 対象者らは, 着任に対しそのまま 素直には受け入れ難い思いを持っていた。選任されたこと への疑問》として,「何故自分なのかと思った」と自身が選 出されたことへの驚きや，「自分より優れている人がいる のに, なぜ私が副師長なのかわからない」といった腑に落 ちない思いを記載していた，なかには，「自分のどこが認め られたのか, 誰にきけばいいのかわからない」といった記 載もあった. また, 《今までの実績と未練》も着任への抵抗 を示す要因となっていた. 看護ケアへの思いや取り組んで いる課題があった対象者らは,「ベッドサイドに行けなく なる」「(副師長着任前に) 計画していた事がスムーズにい かなくなる」と現状が変わることに思いを残していた.

5 記録単位 $(4.3 \%)$ と最も少なかったカテゴリーが【昇格 への意気込み】であった.これは, 《認めてくれたことへの 喜び》《やりたいことができるチャンス》の 2 つのサブカテ ゴリーから構成された. 対象者らは,「職位に就きうれし い」と《認めてくれたことへの喜び》を感じるとともに, 着

表 1 新規着任時の思い

\begin{tabular}{|c|c|}
\hline サブカテゴリー & カテゴリー \\
\hline $\begin{array}{l}\text { 任務遂行への不安 (15 記録単位) } \\
\text { 担うことの重荷 (26 記録単位) }\end{array}$ & 担うことへの煩悶 (41 記録単位：35.3\%) \\
\hline $\begin{array}{l}\text { 自身の立ち位置の理解 }(9 \text { 記録単位 }) \\
\text { モチベーションの維持と向上 (4 記録単位) } \\
\text { 知識の獲得 }(9 \text { 記録単位 }) \\
\text { コミュニケーション能力の向上 ( } 3 \text { 記録単位 })\end{array}$ & 自身に必要とされる力への思案 (25 記録単位：21.6\%) \\
\hline $\begin{array}{l}\text { 自分の力量への不安 }(14 \text { 記録単位 }) \\
\text { スタッフの反応を懸念 }(9 \text { 記録単位 })\end{array}$ & 自身の評価に対する心配 (23 記録単位：19.8\%) \\
\hline $\begin{array}{l}\text { 選任されたことへの疑問 (15 記録単位) } \\
\text { 今までの実績と未練 (7 記録単位) }\end{array}$ & 着任への抵抗 (22 記録単位：19.0\%) \\
\hline $\begin{array}{l}\text { やりたいことができるチャンス }(2 \text { 記録単位 }) \\
\text { 認めてくれたことへの喜び }(3 \text { 記録単位 })\end{array}$ & 昇格への意気込み (5 記録単位：4.3\%) \\
\hline
\end{tabular}


任は「やりたいことがやれる機会」と《やりたいことがで きるチャンス》と捉えており，前向きな気持ちを表出して いた.

\section{4. 認識している役割}

副師長に就任した時点で認識している役割については, 【師長との連携】【スタッフへの働きかけ】【環境作り】【モ デルとして存在】【業務調整】の 5 つのカテゴリーが抽出さ れた (表 2).

認識している役割として，最も記載が多かったのが【師 長との連携】(52 記録単位；34.7\%) であった.このカテゴ リーは,《師長とスタッフの仲介》《師長の代行》《師長の補 佐》《管理者間の協力》の 4 つのサブカテゴリーから構成さ れた、《師長とスタッフの仲介》には,「スタッフの話を聞き， 対応・調整し師長へ報告する」「看護師長とスタッフのパイ プ役である」といった記載がみられた. 対象者らの多くは, 師長とスタッフの間に入ってうまく事が運ぶよう取り持つ 役割が副師長にはあると理解していた，次いで，「師長不在 時の代理業務」といつた《師長の代行》,「師長に情報提供 し調整の手助けをすることである」といった《師長の補佐》 についても役割として取り上げていた.また，《管理者間の 協力》として, 「病棟運営にあたり, 師長・副師長と協力し ていく」といった力を合わせて取り組んでいく体制の必要 性について記載していた。

続いて多かったのが【スタッフへの働きかけ】(44 記録 単位； $29.3 \%)$ であった. このカテゴリーは，《スタッフの 育成》《スタッフとのコミュニケーション》《スタッフ間の 調整》《チーム力の向上》《個々のスタッフ理解》の $5 つ の$ サブカテゴリーから構成された。《スタッフの育成》として, 「病棟の目標 (達成) に向けスタッフを教育する」「スタッフ の学習意欲をあげる声かけ，学習の機会の設定をする」と
いった教育的関わりをあげていた．また，「スタッフとコ ミュニケーションを図り, 意見を吸い上げる」といった《ス タッフとのコミュニケーション》を通して, 情報収集や問 題把握に努めることを取り上げていた.《スタッフ間の調 整》では,「スタッフの能力, 性格, 状況をふまえ調整する」 といったスタッフ間の取りまとめについて,《チーム力の向 上》として「チーム力を高めるための意識づけや声かけ」 について記載しており, 副師長としてスタッフ間, チーム 全体への関わりに目を向けていた，そして，「スタッフの良 いところをみつけて集める」といった《個々のスタッフ理 解》についても取り上げていた.

対象者らは，自身の置かれている場にも目を向けており， 【環境作り】(21 記録単位；14.0\%)の必要性について記載 していた.このカテゴリーは,《職場作り》《職場内の状況把 握》《安全管理》の 3 つのサブカテゴリーから構成された. 《職場作り》は,「働きやすい職場環境をつくる」「笑顔で働 ける職場」といった望ましい環境を取り上げ，そうした環 境を作るのが副師長の役割としていた．また，そのために は「現在の職場のことをよく知る」といった《職場内の状 況把握》について取り上げていた。他には，《安全管理》と して,「安全を常に意識し行動する」ことも自身の課題とし て捉えていた.

【モデルとして存在】 $(17$ 記録単位；11.3\%) は, 《看護実 践のモデル》《スタッフのモデル》の 2 つのサブカテゴリー から構成された. 副師長として, 培ってきた看護への取り 組みや看護師としての姿勢を手本として後輩へ示す役割に ついて記載していた，《看護実践のモデル》には「看護実践 モデルとなる」《スタッフのモデル》には「副師長はスタッ フのモデルとなる」といった, どちらのサブカテゴリーも 短文での記載が多くみられた。なかには，「看護実践モデル となり，自身とスタッフの学ぶ意識を高める」といった熱

表 2 認識している役割

サブカテゴリー

師長の代行 (14 記録単位)

管理者間の協力 (6 記録単位)

師長の補佐 (13 記録単位)

師長とスタッフの仲介 (19 記録単位)

チーム力の向上 $(6$ 記録単位 $)$

スタッフ間の調整 $(7$ 記録単位 $)$

スタッフとのコミュニケーション (11 記録単位)

個々のスタッフ理解 $(5$ 記録単位 $)$

スタッフの育成 (15 記録単位)

職場内の状況把握 (7 記録単位)

職場作り (11 記録単位)

安全管理 (3 記録単位)

スタッフのモデル (4 記録単位)

看護実践のモデル (13 記録単位)

病棟の稼働に関する調整 $(6$ 記録単位 $)$

時間の捻出 $(4$ 記録単位)

部署以外での活動 $(6$ 記録単位)

\section{カテゴリー}

師長との連携 (52 記録単位：34.7\%)

スタッフへの働きかけ (44 記録単位：29.3\%)

環境作り (21 記録単位：14.0\%)

モデルとして存在 (17 記録単位：11.3\%)

業務調整 (16 記録単位：10.7\%) 
意を表す記載もみられた。

【業務調整】 $(16$ 記録単位；10.7\%) は，《病棟の稼働に関 する調整》《部署以外での活動》《時間の捻出》の 3 つのサ ブカテゴリーから構成された. 対象者らは, 副師長には 「ベッド操作・他病棟との調整」「勤務調整・勤務表の作成・ 人員確保」といった職場を滞りなく回す任務があるとして, 《病棟の稼働に関する調整》をあげていた. また, 副師長と して「他部門への交渉力, 行動力」を持ち,「医師, 他職種と 連携した仕事ができる」といった《部署以外での活動》に ついても記載していた.そして,「時間の管理」といった《時 間の捻出》も重要な務めとしていた.

\section{5. カテゴリーの信頼性}

看護学研究者 1 名に各段階のカテゴリーの再分析を依頼 し，カテゴリー分類の一致率をスコットの計算式に基づき 算出した. その結果, 着任時の思いの一致率は, $100 \%$, 認識 している役割の一致率は, $81.4 \%$ であった.どちらも, 一致 率 70\%以上であり, 信頼性は確保された。

\section{$\mathrm{V}$ 考察}

\section{1. 管理者になることへの思い}

対象者らにとって，いちスタッフから管理者になるとい う立場の転換は，多くの葛藤をもたらしていることが分 かった.【担うことへの煩悶】や【着任への抵抗】といった 後ろ向きな思いの背景には, 副師長としてどのような力が 求められているのか，あるいはどのような役割を担えばい いのかといった能力や役割の曖昧さ5゙が影響していると考 えられた。

看護職に打ける昇進に関する人事システムは, 組織に

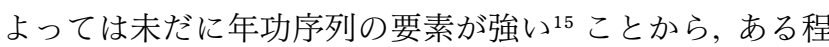
度の年齢に達すると着任への準備ができているのではない か, と推測していた. しかし, 着任への否定的な思いが抽出 されたことは, 本研究における対象者らの年齢が関係して いたのではないかと推測する. 対象者らのうち最も年齢の 高い者は 49 歳であり, 平均年齢が 43 歳であったことを踏 まえると，年齢が上がるにつれ副師長昇格へのチャンスを あきらめつつあったのではないかと思われた

また,【自分の評価に対する心配】といった自信のなさは, 自分はスタッフの手本になるような存在ではない5といつ た思いが反映されたのではないかと考える，さらに，副師 長も被る中堅看護師の世代は, 新人看護師と比較して, 看 護ケアに関するストレスは低下するものの，人間関係のス トレスが上昇するとされており, ${ }^{16}$ そうした人間関係への 軋軪が《スタッフの反応を懸念》する状況を生んでいると も推測された。

看護に関する能力は, 臨床経験年数とともに高まるが, その中身に関しては個人差が大きくなる ${ }^{15}$ とれている. 本研究においても，【自身に必要とされる力への思案】につ
いての記載が多く, ある程度の経験を積んだ世代において も能力開発の機会を設ける15,16 ことは重要であると考え る. ただ，周囲の役割期待といった葛藤を抱えている副師 長が, 自らその葛藤を克服する能力も求められている とから, 副師長自身が自分を律する力を獲得することも必 要と思われた。

記載は少なかったものの，【昇格への意気込み】を率直に 表しているものもみられた. そして,《今までの実績と未練》 といった, スタッフとしての看護への取り組みや, 看護実 践への思いに摇らいでいることも窺えた。 福岡 ${ }^{5} の$ 報告に は, 副師長も看護実践が好きで, それをやりがいと感じて いるとあり，こうした看護への思いが着任により削がれて しまうのではないかといった思いが未練となって表出した と思われる。

《選任されたことへの疑問》には,「自分のどこが認めら れたのかわからない」といった着任への後ろ向きな思いが 記載されていた，自身について客観的に評価できていない ことが考えられるが, 周囲からの適切なフィードバックや 承認を受けていないことも推測された. 着任して間もない 副師長には，できることは認めるなどこまめなフィード バックが大切 5 とされているが，このことはスタッフの時か らの承認が重要であることも示唆していると考える. 着任 前のスタッフの時から, 他者からの承認を適切に受けてい れば，自ずと自己肯定感が高まるのではないかと思われた。

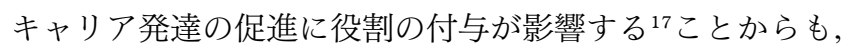
着任を前向きに捉えられる自己評価が可能となるような管 理者の意図的な関わりが重要であるといえる。

\section{2. 認識している役割内容}

対象者らが認識している【師長との連携】【スタッフへの 働きかけ】【モデルとして存在】【業務調整】といった副師 長の役割は, 概小先行研究5,18,19 と同様のものであった。

近年, 進められている医療制度改革により, 対象者らの 勤務する医療施設においても経営に重点が置かれた対策が とられていると思われる. そうした中で看護組織の見直し も求められていることを踏まえると, 人事面や職務内容を 見直す必要性から【業務調整】への取り組みが重要と思わ れる. 今回の結果では, 【業務調整】に関する記載は少なく, 調整に関する内容は対象者らのなかでは【師長との連携】 の細項目として位置付けられていたのではないかと推測す る.また，最終的な責任は師長が持っているといった権限 を踏まえた甘えや，師長からの指示によって任務を遂行す るといった受け身的な姿勢も考えられた。

ただ，副師長に限らず，中堅看護師に期待されている能 力としてリーダーシップの発揮や職場の改善といった役割 を遂行する能力 ${ }^{15}$ があげられており, 本研究で抽出された 《職場作り》は重要な役割であるといえる。そのためには, 副師長はアンテナを広げてスタッフが出している情報や患 者の現状に注意を払う ${ }^{18}$ 必要があり, 対象者らも同様に 
「チーム内の状況把握」や「病棟内における患者把握」と いった《職場内の状況把握》を取り上げていた。こうした状 況を把握するといった役割は，最近まで，いちスタッフで あったこと，そしてスタッフと近い存在であるといった， 看護師長では叶わない情報を獲得できる副看護師長の特権 であるといえる. 副師長は，こうした自身の強みをチーム 活性化に有効に活用し, その意義を顕在化させていくこと が重要であると考える。

\section{3. 副看護師長のキャリア発達とその支援}

副師長となった対象者らが,【自身に必要とされる力への 思案】を繰り返しながら【モデルとして存在】という役割 の実現に向けキャリア発達し, 後の師長として活躍するた めには，学習の機会は欠かせないと思われる，その際，キャ リア発達の基盤である職業継続の明確な意思, そしてチャ

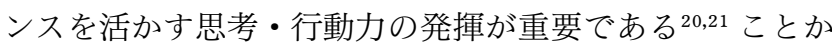
ら, 受け身ではなく能動的な行動が期待され, 自らの動機 付けで学習の機会をつかんでいく姿勢が求められていると 考える.今回の副師長への着任という役割の付与が，こう した意欲を奮い起こすきっかけになることが望まれる.

さらに，《今までの実績と未練》にあるように，スタッフ として取り組んでいた業務や，《職場作り》のなかで課題と 感じている問題点に関して, 所属部署の管理者は取り組み を理解し，その意志を尊重することが重要と考える. 取り 組み課題が途切れることは, 副師長だけでなく, 一緒に取 り組んでいたスタッフの気持ちを萎えさせることにもつな がり，組織に不利益を生じる可能性も考えられる。やり い看護の中断が看護を極める思いを削ぎ，キャリア発達を

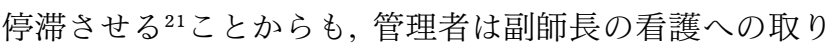
組みや思いを理解し，支援していくことが重要であるとい える。

また, 副師長が着任に際し “なぜ私が”といった腑に落 ちない思いを抱えている場合，当事者のみならず，周囲の スタッフへも負の連鎖が生じかねない. 役割の増大，そし て責任の付与が，気持ちを引き締める効果となるよう，そ して着任を前向きに捉えることで気持ちの転換を行えるよ う，管理者は副師長着任に至った評価とともに意識的に正 のフィードバックを返していく関わりが重要になると思わ れる，そうした管理者の姿が，副師長にとって人材育成の モデルとなり，《個々のスタッフ理解》にあったように「ス タッフの良いところを見つけて襄める」行動の後押しにつ ながると考える.

これまでも看護者のキャリア発達を促す要因として, 他 者からの肯定的な評価が重要 ${ }^{19}$ とれており，管理者がこ の役割を担う者として取り上げられている.ただ，新卒看 護師の離職防止・実践能力の向上から始まり, 病院の機能 評価, 医療安全対策, モンスターペイシェントへの対応と, 管理者の抱える業務は増大するとともに複雑化している. 管理者だけに期待するのではなく，日頃よりスタッフ間で
の承認や正のフィードバックがやり取りされている職場で あれば，自然と自己肯定感が高まることが期待できると考 える. 周囲からのフィードバックを受けることで，自身を 客観的に評価することが可能となれば，自ずと自身の担う 役割を識別・理解し, 周囲からの期待にも応えていくこと が可能になると考える.

今回の結果を踏まえて, 安易に管理者のみにキャリア発 達支援の義務があると考察するのではなく, スタッフ間の 承認やサポート, 的確なフィードバックが行われることで スタッフ個々の自己肯定感がアップすれば, 組織の活性化 が期待でき，キャリア発達を支援する風土が生まれると推 測する. スタッフに近い副師長がそうした風土がうまれる よう, 【環境作り】の役割を担いながら, 率先して承認やサ ポートを実践するモデルとなることが必要と考える.

\section{VI 本研究の限界と課題}

本研究は, 調査対象者が限られているため, 副師長の現 状として一般化するには限界がある. 今後, 調査場所を拡 大するとともに，調査対象者を増やして更なる検討を重ね る必要がある。

また，キャリア発達の円滑なプロセスを辿れる職場風土 を作っていくには，管理者のみならず，まずはスタッフ一 人ひとりが他者と関わる際の姿勢に目を向ける必要がある と思われる，どういった取り組みが必要であるか，これか ら十分検討し検証していきたいと考えている.

\section{VII 結論}

副師長に新規着任した時の思い, そして認識している役 割について自記式質問紙調査を行った。その結果, 新規着 任時の思いとして，【担うことへの煩悶】【自身に必要とさ れる力への思案】【自身の評価に対する心配】着任への抵 抗】昇格への意気込み】のつのカテゴリーが抽出された. また, 就任した時点で認識している役割については, 【師長 との連携】【スタッフへの働きかけ】【環境作り】【モデルと して存在】【業務調整】の 5 つのテゴリーが抽出された. 副師長は, いちスタッフから管理者になるという立場の 転換に戸惑い，【担うことへの煩悶】や【着任への抵抗】と いった後ろ向きな思いを抱えていると考えられた，ただ， 職場内の改善といつた【環境作り】に着目するなど, スタッ フであったからこそ感じている役割を認識していることが 推測された.いちスタッフであったこと，そしてスタッフ と近い存在であることは, 副看護師長の特権であるといえ， こうした自身の強みをチーム活性化に有効に活用し, その 意義を顕在化させていくことが重要であると考える.

なお，本研究は新潟県立看護大学平成 21 年度看護交流 センター地域課題研究の助成を受けて実施した研究の一部 
である.

\section{引用文献}

1. 厚生労働省医政局看護課. 看護基礎教育の充実に関する検 討会報告書 2007 .

2. 西村伊知恵. 看護管理者から看護教員に戻って得た気づき. 看護教育 2008; 49(9): 812-815.

3. 千葉大学大学院看護学研究科附属看護実践研究指導セン ター 組織変革型看護職育成支援データベース．福田美登 里. 平成 21 年度国公私立大学病院副看護部長研修. http://www.np-portal.com/report/years/4/1(2017/05/03)

4. 永見瑠美子. 看護組織における副師長の自己効力感に関す る研究. 看護実践の科学 2003; 28(4): 60-65.

5. 福岡由紀. $\mathrm{N}$ 県内に拈ける副師長のやりがいに関する看護 管理的視点からの分析. 日本看護管理学会誌 2007; 11(1): 49-56.

6. 武村雪絵 (編). 看護管理に活かすコンピテンシー. 東京: メ ヂカルフレンド社, 2014.

7. 寺岡三左子. 主任看護師が捉えた主任としての役割. 日本看 護管理学会誌 2011; 15(2): 158-165.

8. 平田明美, 戸梶两紀彦. 病棟看護師長の役割認識に関する研 究, 日本医療・病院管理学会誌 2013; 50(4): 15-24.

9. 塚崎恵子. 看護管理者の役割認識と行動. 全国自治体病院協 議会雑誌 2009; 48(3): 22-26.
10. 倉岡有美子. 仕事上の困難を感じた看護師長の成長に関す 了質的研究. 日本医療・病院管理学会誌 2016; 53(1): 41-49.

11. 舟島なをみ. 質的研究への挑戦. 東京: 医学書院 1999: 4253.

12. Berelson, B. 稲葉三千男, 他訳. 内容分析. 東京 : みすず書房 1957.

13. 上野栄一. 内容分析とは何か一内容分析の歴史と方法につ いて一. 福井大学医学部研究雑誌 2008; 9(1): 1-18.

14. 中谷啓子, 舟島なをみ, 杉森みど里. 授業過程を評価する学 生の視点に関する研究. 看護教育学研究 1998; 7(1): 16-30.

15. 小山田恭子. 我が国の中堅看護師の特性と能力開発手法に 関する文献検討. 日本看護管理学会誌 2009; 13(2): 73-80.

16. 石井京子, 星 和美, 藤原千恵子ら. 中堅看護師の職務ス卜 レス認知がうつ傾向に及ぼす要因分析に関する研究. 日本 看護研究学会雑誌 2003; 26(4): 21-30

17. 水野暢子, 三上れつ. 臨床看護婦のキャリア発達過程に関す る研究. 日本看護管理学会誌 2000; 4(1): 13-22.

18. 林 容子. 医療変革期における副師長の役割遂行のあり様. 日本看護管理学会誌 2009; 12(2): 45-52.

19. 森本妙子, 十亀美千代. スタッフがとらえた副看護師長の役 割ナーシングビジネス 2009; 3(4): 382-389.

20. グレッグ美鈴, 池邊敏子, 池西悦子ら. 臨床看護師のキャリ ア発達の構造. 岐阜県立看護大学紀要 2003; 3(1): 1-8.

21. 土佐千栄子, 出口昌子, 上野貴子ら. 経験 3 年目以上の看護 婦-看護士の臨床実践能力の特徵 第 1 報. 日本看護管理学 会誌 2002; 5(2): 64-70. 


\title{
The Role Recognition of Assistant Head Nurses and Their Thoughts Upon Assuming Their Posts
}

\author{
Noriko Okamura ${ }^{1}$, Youko Aoki ${ }^{2}$ and Reiko Watanabe ${ }^{3}$ \\ 1 Niigata College of Nursing, 240 Shinnan-cho, Joetsu, Niigata 943-0147, Japan \\ 2 Niigata Rheumatic Center, 1-2-8 Hon-cho, Shibata, Niigata 957-0054, Japan \\ 3 Niigata Nurse Center, 2-11 Kawagishi-cho, Chuo-ku, Niigata 951-8133, Japan
}

\section{Abstract}

Purpose: This study aims to clarify what thoughts assistant head nurses embraced at the time they newly took up their posts, and how they recognized their roles.

Methods: The participants were 37 nurses who had been appointed assistant head nurses. A self-administered questionnaire was used to investigate three research themes: "Thoughts upon assuming the post of assistant head nurse"; "Recognition of the role of the assistant head nurse at the time", and "Current issues".

Result: Five categories of thought upon assuming the post of assistant head nurses were identified: (1) anxiety over responsibility; (2) perceptions regarding the ability of being needed; (3) anxiety over evaluation to themselves; (4) reticence to taking up the post; (5) enthusiasm about the promotion. Five further categories were identified regarding recognition of the roles of an assistant head nurse at the time of assumption of office: (1) cooperation with head nurse; (2) approach towards the staff; (3) environmental organization; (4) being a role model; (5) operational regulation.

Conclusion: While the assistant head nurses were bewildered by aspects of the change of position such as "the anxiety of bearing responsibility", they recognized their role as a member of staff was to focus on improvement in the workplace such as "environmental organization".

\footnotetext{
Key words:

assistant head nurses,

thoughts upon assuming a position,

role recognition
} 